\section{Reincarnation, Self-Realization, and Animal Protection}

\author{
Michael W. Fox \\ The Humane Society of the \\ United States
}

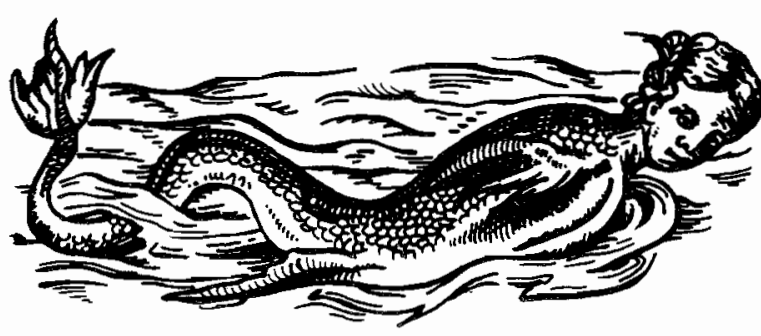

Belief in reincarnation, in the immortality, transmigration, and eventual salvation and liberation of the soul is alien to western thinking and religious tradition. The notion that believers in reincarnation even treat insects with compassion because one bug could be a deceased parent or grandparent is to totally misrepresent and grossly oversimplify this belief system. On the contrary, compassion toward all sentient beings is based on the contention that they are ensouled beings and that all living beings are interrelated as well as interdependent because they are part of the same creation.

As embraced by some Jains, Hindus and Buddhists, life is seen as process, stage and transformation: Impermanence linked with interdependent existence, and individuality with the unity of origin of all beings arising from the same first cause.

The first cause or Father-Mother of all is manifest reality, the Pure Light of the Dharma path or Tao of cosmic communion within an infolding and unfolding time-space continuum of conscious energy wherein each entity has its own karma and dharma.

Of the myriad jivas or souls in this seamless web of Creation, those of the animal kingdom concern me especially. My concern is my choice of heart. I have no

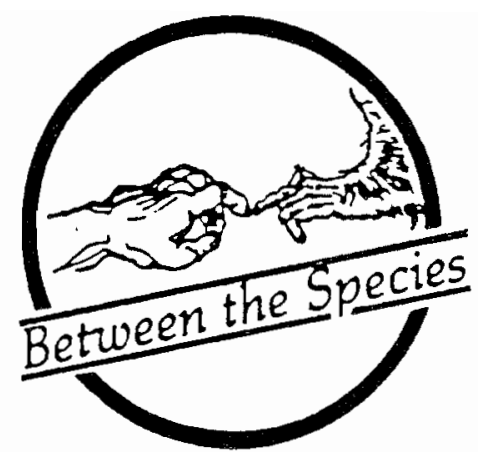

aspirations that by helping alleviate and prevent the suffering of animals under humankind's insensitivity I will gain fame or spiritual advancement. On the contrary, my Spirit bleeds for the suffering of all Creation and for the fate of a humanity that has not yet been able to liberate itself from himsa: from acts of violence and from countering evil with evil. As Leo Tolstoy observed in his book My Religion (which deeply influenced and affirmed Mahatma Gandhi's philosophy), "Ninety-percent of the world's suffering is caused by our attempts to avoid the unavoidable ten-percent."

Through self-transformation (by realizing the true nature of the self) we are moved to help the souls of the plant and animal kingdom which we might harm in so many ways, to realize their salvation and liberation and enjoy the times of bliss this blessed Earth-space offers: For bee and flower and sun and grass to meet and mingle as we pass amongst them in the pure light of ahimsa, seeing life, giving to life as we love life, serve life, live and let live, and praise and bless the beasts.

To adopt the fatalistic view that another's suffering is its own Karma and not also one's own concern, is a soul or self-limiting attitude. Likewise accepting the accelerating rate of human-caused extinction of animal species because it is the price of progress, or because their souls are immortal and so can go somewhere else, is surely wrong-minded. The journeying soul in human

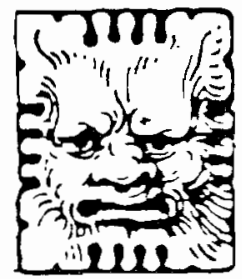


form eventually resolves itself and like the dew upon the grass, gives more to life than it takes; and in passionate empathy becomes the embodiment of ahimsa and an agent of compassion. It chooses not to seek its own liberation from the world until all sentient life is freed from human oppression and suffering.

Such an attitude and way of life accords with the true nature of reality for, as Thomas Berry has said, "the world is a communion of subjects and not a collection of objects." It is only when we objectify others that we harm them, and in the process of so distancing ourselves, we harm ourselves. Ultimately we feel alone, alienated and so far from any sense of kinship, belonging and communion that life has no meaning beyond the gratification of our material wants and needs.

We harm ourselves when we pollute the environment and let boundless violence spread as we continue to justify the exploitation and suffering of animals, the virtual annihilation of the natural world; and the use of evil means against other evils rationalized as being necessary for some greater good: like war and vivisection; genocide and ecocide. Only that which is sacred is secure; hence our security will come when we sanctify life and treat all living beings with respect and reverence.

The degradation of the human spirit continues as the suffering of all sentient life and the degradation and desecration of the Earth intensifies. This retrograde process seems to be ever more irreversible as it intensifies, but this need not be so. It is ultimately an issue not for government or science and technology to correct, but rather it is a question of choice, an ethical and spiritual issue over which we have control once we realize the virtues of self-control and ahimsa: and experience the truth of tat-tvam-asi.... Thou art that. Such self-realization cannot be achieved without active involvement in animal and environmental protection (macro-ahimsa) as well as being a responsible and responsive member of one's own community and religious tradition (micro-ahimsa). ${ }^{1}$

To live and let live and to love all and serve all are the basic elements of a truly humane society and of a sustainable and just global community. The Jain saint Mahavira said some 2,500 years ago, "You are that which you intend to hit, injure, insult, torment, persecute, torture, enslave or kill. Thus a wise man should not act sinfully towards animals, nor cause others to act so, nor allow others to act so. Having thus learned the nature of living beings which is in accordance with the principles of reasoning, and believing in it, a person should delight in self-control. Then he or she will be delivered from all misery."

The following stanza from a Chinook Amerindian blessing litany fully expresses the necessary element of humility and gratitude toward nature:

We call upon the land which grows our food, the nurturing soil, the fertile fields, the abundant gardens and orchards, and we ask that they teach us and show us the way.

Human survival and the well-being of the animal and plant kingdoms now, more urgently than ever, depend upon us all embracing the Jain religion's principle of ahimsa, of living conscientiously to avoid causing harm to other living beings.

As the Jain Acaranga Sutra states: "all breathing, existing, living, sentient creatures should not be slain, nor treated with violence, nor abused, nor tormented, nor driven away. This is the pure, unchangeable eternal law" (attributed to Mahavira circa 550 B.C.).

The modern hero is surely one who actively affirms ahimsa in both professional and personal life realms, and rather than remaining passive or indifferent toward the myriad crimes of violence against creatures and creation, seeks every means to expand the principle of ahimsa wherever it is needer. That humans can be the most inhuman of all animals is probably the reason why humanity continues to suffer, since inhumanity knows no bounds. It is not a question of us drawing some arbitrary line in terms of which creatures and to what extent we should exploit them. Rather, we should draw a circle, a boundless circle of compassion to include all creatures and creation within the scope of our respect and reverence. By so doing, the significance of our own lives is enriched and our own spiritual development enhanced.

\section{Realizing the Sacred}

When we realize that every living thing and every aspect of the natural world, including ourselves, is sacred, part of divine conception, we are moved to live in a more reverential way. This is because when we begin to respect the environment and show compassion toward animals, we gain a more intimate, empathic knowledge. This panempathetic knowledge moves us to cause the least harm and the greatest good as possible. 
The dawning of the sacred is our realization of the co-inherent and imminent, as well as omnipresent and transcendent divine quality in every natural Creation, both animate and inanimate, including ourselves. This worldview is the theological basis for panentheism as distinct from pagan pantheism.

As ecology reveals the instrumental interdependence of living entities and systems, so a deeper empathetic connection with the natural world provides spiritual evidence of an intelligent, self-organizing life force that is manifest in biological diversity and mirrored in our cultural and religious diversity.

We are part of this life force, what Plato called the anima mundi or Earth-soul, and yet in our attempts to master it, to commoditize it and variously squander and desecrate it, we bring evil and suffering into the world.

When did we last have a conversation with a tree; praise the rain; help another injured or needy fellow being; celebrate the songs of birds at dawn; and thank the soil?

Since we are part of this life force, part of us is therefore immortal. The monotheistic Judaeo-Christian and Islamic religions hold that only the human soul is immortal, and has only one lifetime on Earth. This view is not shared by the majority of peoples, especially of Hindu, Jain and Buddhist religious traditions. Every soul-Atman, divine spark or Jiva-has its own purpose and fulfillment in countless lifetimes and in myriad forms. Whether or not people believe in reincarnation and in the immortality of the soul, the sacred, numinous dimension of all Creation can touch and inspire us to live gently on the Earth with respect and reverence for all life.

\section{Notes}

${ }^{1}$ I appreciate these distinctions of macro- and microahimsa suggested by Dr. Sulekh Jain.

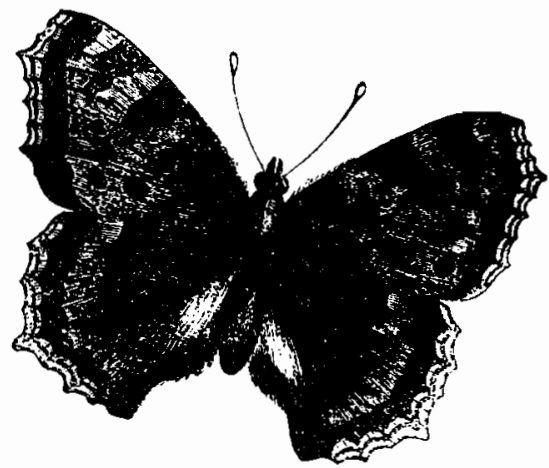

\section{Books Received}

\section{Steve Baker}

PICTURING THE BEAST

Animals, Identity and Representation

New York: Manchester University Press, 1993

Distributed in U. S. by St. Martin's Press

list of figures, acknowledgements, preface, 232p,

notes, index

$\$ 69.95$ hardcover $\$ 16.95$ paper

Birgitta Forsman

RESEARCH ETHICS IN PRACTICE

The Animal Ethics Committees in Sweden, 1979-1989

Göteborg: Centre for Research Ethics, 1993

prologue, foreward, $101 \mathrm{p}$, references, list of

abbreviations, index of names

$\$ 12.00$ paper

\section{Ann Cottrell Free}

SINCE SILENT SPRING:

Our Debt To Albert Schweitzer \& Rachel Carson

Washington: The Flying Fox Press, 1992

$18 \mathrm{p}$

paper/no price stated

Clay Lancaster

THE ARTS AND CRAFTS OF THE ANIMALS

Salvisa, KY: Warwick Publications, 1993

preface, 55p, suggested books, list of illustrations

$\$ 6.00$ paper

Marian Scholtmeijer

ANIMAL VICTIMS IN MODERN FICTION:

From Sanctity to Sacrifice

Toronto: University of Toronto Press, 1993

297p, notes, selected bibliography, index

paper/no price stated

\section{SOCIETY AND ANIMALS}

Social Scientific Studies of the Human Experience of Other Animals

Vol. 2 No. 1, 1994

Cambridge, UK: The White Horse Press, 1993 93p

subscription rate ( 2 issues): $\$ 30.00$ /individuals 